\title{
Ảnh hưởng của một số nhân tố ngoại sinh lên sự tăng trưởng và tích lũy lipid ở vi tảo Haematococcus Pluvialis Flotow
}

\section{Effects of some exogenous factors on growth and lipid accumulation of microalgae Haematococcus Pluvialis Flotow}

\author{
Nguyễn Trần Đông Phương ${ }^{1,2^{*}}$, Lê Huyền Ái Thúy ${ }^{2}$, Bùi Trang Việ̣t ${ }^{1}$ \\ ${ }^{1}$ Trường Đại học Khoa học Tự nhiên, ĐHQG Thành phố Hồ Chí Minh, Việt Nam \\ ${ }^{2}$ Trường Đại học Mở Thành phố Hồ Chí Minh, Việt Nam \\ *Tác giả liên hệ, Email: nguyentrandongphuong@ gmail.com
}

\section{THÔNG TIN}

DOI:10.46223/HCMCOUJS. tech.vi.13.1.451.2018

Ngày nhận: 20/07/2018

Ngày nhận lại: 26/09/2018

Duyệt đăng: 15/10/2018

Tù khóa:

haematococcus pluvialis, kim loại nặng, sốc nhiệt độ, tăng trưởng, tích lũy lipid

\section{TÓM TÁT}

Tế bào vi tảo Haematococcus pluvialis được nuôi cấy trong bình $500 \mathrm{~mL}$ chứa $250 \mathrm{~mL}$ môi trường lỏng $\mathrm{BB}$ được sục khí, theo hai giai đoạn, với mật độ tế bào ban đầu là $4,3 \cdot 10^{3}$ tế bào $/ \mathrm{mL}$. Tất cả các thí nghiệm được đặt ở nhiệt độ $25 \pm 3^{\circ} \mathrm{C}$, cường độ ánh sáng huỳnh quang $50 \mu \mathrm{mol}$ photon $\mathrm{m}^{-2} \mathrm{~s}^{-1}$ và thời gian chiếu sáng 12 giờ/ngày, trừ các xử lý với ánh sáng đèn LED. Sau 7 tuần nuôi cấy trong môi trường $\mathrm{BB}$ (giai đoạn 1), một số nhân tố ngoại sinh gồm ánh sáng đèn LED trắng, đỏ $(610-760 \mathrm{~nm})$ và lục $(460$ $490 \mathrm{~nm}$ ) đều ở cường độ $50 \mu \mathrm{mol}$ photon $\mathrm{m}^{-2} \mathrm{~s}^{-1}$ (xử lý trong 3 tuần, 24 giờ, hay gián đoạn đêm 30 phút), sốc nhiệt độ $\left(50^{\circ} \mathrm{C}\right.$ trong 1,5 hay 2 giờ, $7 \pm 3^{\circ} \mathrm{C}$ trong 2, 3, 4 hay 6 giờ, $0 \pm 2^{\circ} \mathrm{C}$ trong 1,5 hay 2 giờ), kim loại nặng (bổ sung $\mathrm{Cu}^{2+}, \mathrm{Fe}^{2+}, \mathrm{Mg}^{2+}, \mathrm{Zn}^{2+}$ với nồng độ cao gấp 1,5 hay 2 lần so với môi trường $\mathrm{BB}$ ), hoặc $\mathrm{NaCl} 0,5$; 0,9 hay $3,0 \%$ được áp dụng trong giai đoạn 2 ( 3 tuần) để khảo sát sự tăng trưởng và tích lũy lipid ở vi tảo. Sau 10 tuần nuôi cấy, kết quả cho thấy, chỉ có xử lý ánh sáng đèn LED đỏ trong 24 giờ làm tăng lượng dầu sinh học, nhưng làm giảm trọng lượng tươi và khô so với đối chứng (ánh sáng huỳnh quang). Xử lý $7 \pm 3^{\circ} \mathrm{C}$ trong 2 giờ làm tăng hàm lượng dầu sinh học và thay đổi không đáng kể trọng lượng tươi, nhưng giảm trọng lượng khô. Các xử lý $\mathrm{Cu}^{2+}$, $\mathrm{Fe}^{2+}, \mathrm{Mg}^{2+}$ và $\mathrm{Zn}{ }^{2+}$ với nồng độ cao gấp 1,5 hay 2 lần làm giảm hoặc không tăng hàm lượng dầu sinh học. Xử lý $\mathrm{NaCl} 0,5 \%$ làm tăng hàm lượng dầu sinh học, nhưng làm giảm trọng lượng tươi và khô.

\section{ABSTRACT}

Haematococcus pluvialis cells were cultured in 500-ml bottles in two stages, each contained $250 \mathrm{ml}$ of liquid BB medium 
Keywords:

growth, haematococcus pluvialis, heat shock, heavy metal, lipid accumulation with aeration and an initial cell density of $4.3 \times 10^{3}$ cells $/ \mathrm{mL}$. All the experiments were carried out at $25 \pm 3^{\circ} \mathrm{C}$, and under the effect of fluorescence light $\left(50 \mu \mathrm{mol}\right.$ photon $\mathrm{m}^{-2} \mathrm{~s}^{-1}, 12 \mathrm{~h} / 12 \mathrm{~h}$ light/dark cycle), except the experiments under the effect of LED lighting. After 7 weeks culture in BB medium (phase 1), some exogenous factors including LED light (intensity of $50 \mu \mathrm{mol}$ photon $\mathrm{m}^{-2} \mathrm{~s}^{1}$ ): white, red (610 - 760nm) and blue (460 - 490nm) (treatment in 3 weeks, or 24 hours, or a 30 -minute night interruption), heat shock $\left(50^{\circ} \mathrm{C}\right.$ during 1.5 or 2 hours, $7 \pm 3^{\circ} \mathrm{C}$ during $2,3,4$ or 6 hours, and $0 \pm 2^{\circ} \mathrm{C}$ during 1.5 or 2 hours $)$, heavy metals $\left(\mathrm{Cu}^{2+}, \mathrm{Fe}^{2+}, \mathrm{Mg}^{2+}\right.$, $\mathrm{Zn}^{2}$ and $\mathrm{NaCl}$ at high concentrations during 3 days) were applied to study growth and lipid accumulation in Haematococcus pluvialis. After 10- week culture, the results showed that only red LED light treatment for 24 hours increased the biodiesel content, but reduced the fresh weight and the dry weight compared to the control (under the effect of fluorescent light). Treatment of $7 \pm$ $3^{\circ} \mathrm{C}$ for 2 hours increased the biodiesel content and did insignificantly change the fresh weight, and reduced the dry weight. The treatments of $\mathrm{Cu}^{2+}, \mathrm{Fe}^{2+}, \mathrm{Mg}^{2+}$ and $\mathrm{Zn}^{2+}$ in 1,5 or double concentration not increase the biodiesel content. The treatment of $0.5 \% \mathrm{NaCl}$ increased the biodiesel content, but reduced the fresh weight and the dry weight.

\section{Mở đầu}

Sản xuất dầu diesel từ vi tảo được xem là phương pháp khả thi do không cạnh tranh đất sản xuất nông nghiệp và không làm ô nhiễm môi trường. Tảo lục nước ngọt $H$. pluvialis Flotow được chứng minh là vật liệu chứa nhiều dầu sinh học và astaxanthin, một chất màu có giá trị kinh tế cao. Quá trình tích lũy lipid xảy ra trong tế bào $H$. pluvialis ở giai đoạn tạo nang được cảm ứng bởi stress như dinh dưỡng giới hạn, cường độ ánh sáng cao, $\mathrm{FeSO}_{4} 450 \mu \mathrm{M}$ hoặc sodium acetate $45 \mathrm{mM}$ kích thích sự tích lũy lipid (Lei et al., 2012). Trong các nghiên cứu trước đây, nhóm chúng tôi đã xác định nồng độ $\mathrm{BA}$, IAA và GA3 có ảnh hưởng đến sự tăng trưởng và tích lũy lipid ở vi tảo $H$. pluvialis (Nguyen, Le, \& Bui, 2015). Bên cạnh đó, chúng tôi còn tối ưu hóa qui trình xác định các gene mã hóa cho enzyme khởi đầu (biotin carboxylase, $\mathrm{BC}$ ) và kết thúc (fatty acyl-acyl carrier protein thioesterase, FATA) của quá trình sinh tổng hợp lipid ở vi tảo H. pluvialis (Nguyen, Lao, Le, \& Bui, 2016). Nghiên cứu này được thực hiện nhằm tìm hiểu sự tăng trưởng và tích lũy lipid ở vi tảo $H$. pluvialis Flotow dưới tác động của số yếu tố gồm có loại ánh sáng, nhiệt độ, kim loại, nồng độ muối.

\section{Vật liệu và phương pháp}

\section{Vật liệu}

Vi tảo H. pluvialis Flotow được phòng Sinh học thực nghiệm của Viện Nghiên cứu và Nuôi trồng Thủy sản II, TP. Hồ Chí Minh cung cấp lại từ bộ sưu tập giống tảo của phòng Công 
nghệ Tảo, Viện Công nghệ Sinh học thuộc Viện Hàn lâm Khoa học và Công nghệ Việt Nam, Hà Nội.

\section{Phương pháp}

$50 \mathrm{~mL}$ vi tảo ở tuần thứ 9 , được nuôi trong bình $500 \mathrm{~mL}$ có chứa $250 \mathrm{~mL}$ môi trường lỏng $\mathrm{BB}$ với $\mathrm{pH} 7$ được sục khí, mật độ tế bào ban đầu $4,3.10^{3}$ tế bào/mL, được dùng để bố trí thí nghiệm. Tất cả các thí nghiệm được đặt ở nhiệt độ $25 \pm 3{ }^{\circ} \mathrm{C}$, cường độ ánh sáng huỳnh quang $50 \mu \mathrm{mol}$ photon $\mathrm{m}^{-2} \mathrm{~s}^{-1}$ và thời gian chiếu sáng 12 giờ/ngày trừ các xử lý với ánh sáng LED.

\section{Ảnh hưởng của loại ánh sáng lên sự tăng trưởng và tích lũy lipid của vi tảo}

Vi tảo sau 7 tuần nuôi cấy dưới ánh sáng huỳnh quang (thời gian chiếu sáng 12 giờ/ngày) được chuyển sang ánh sáng LED trắng phổ rộng hoặc LED đỏ với bước sóng 610 - 760nm hoặc LED xanh với bước sóng 460 - 490nm trong 3 tuần tiếp theo, hoặc đặt dưới ánh sáng LED trắng, LED đỏ hoặc LED xanh trong 24 giờ liên tục, hoặc xử lý một lần gián đoạn đêm trong 30 phút từ lúc 0 giờ đến 0 giờ 30 phút tối. Tất cả các loại ánh sáng LED trắng, đỏ, xanh và đèn huỳnh quang trong thí nghiệm này đều ở cường độ ánh sáng $50 \mu \mathrm{mol}$ photon $\mathrm{m}^{-2} \mathrm{~s}^{-1}$.

\section{Ảnh hưởng của xử lý nhiệt độ lên sự tăng trưởng và tích lũy lipid của vi tảo}

Vi tảo sau 7 tuần nuôi cấy được xử lý ở nhiệt độ $50^{\circ} \mathrm{C}$ bằng cách đặt bình chứa vi tảo trong nồi cách thủy trong 1,5 hoặc 2 giờ. Xử lý từ -3 tới $0^{\circ} \mathrm{C}$ bằng cách đặt bình chứa vi tảo ở ngăn đông tủ lạnh trong 1,5 hoặc 2 giờ. Xử lý nhiệt độ từ 4 tới $10^{\circ} \mathrm{C}$ bằng cách đặt bình chứa vi tảo ở ngăn mát tủ lạnh trong 2, 3, 4 hay 6 giờ.

tảo

Ảnh hưởng của $\mathrm{Cu}^{2+}, \mathrm{Fe}^{2+}, \mathrm{Mg}^{2+}$ và $\mathrm{Zn}^{2+}$ lên sự tăng trưởng và tích lũy lipid của vi

Vi tảo sau 7 tuần nuôi cấy trong bình chứa môi trường lỏng $\mathrm{BB}$ được sục khí được chuyển sang môi trường $\mathrm{BB}$ mới có sự gia tăng nồng độ các kim loại nặng trong 3 ngày: $\mathrm{CuSO} 4$ : 2,355mg/L (gấp 1,5) hoặc 3,14mg/L (gấp đôi), $\mathrm{MgSO}_{4}: 112,5 \mathrm{mg} / \mathrm{L}$ (gấp 1,5) hoặc $150 \mathrm{mg} / \mathrm{L}$ (gấp đôi), $\mathrm{FeSO}_{4}$ : 7,47mg/L (gấp 1,5) hoặc 9,96mg/L (gấp đôi), $\mathrm{ZnSO}_{4}: 13,23 \mathrm{mg} / \mathrm{L}$ (gấp 1,5) hoặc $17,64 \mathrm{mg} / \mathrm{L}$ (gấp đôi).

Ảnh hưởng của nồng độ muối $\mathrm{NaCl}$ trong môi trường nuôi cấy lên sự tăng trưởng và tích lũy lipid của vi tảo

Vi tảo sau 7 tuần nuôi cấy trong bình chứa môi trường lỏng $\mathrm{BB}$ được sục khí được chuyển sang môi trường $\mathrm{BB}$ mới được bổ sung $\mathrm{NaCl}$ ở tỉ lệ $0,5 \%, 0,9 \%, 1,5 \%, 3,0 \%$ trong 3 tuần hoặc môi trường bổ sung $\mathrm{NaCl} 1,5 \%, 2,0 \%, 3,0 \%, 3,5 \%$ trong 24 giờ.

\section{(A) Hàm lượng dầu sinh học từ vi tảo}

$1 \mathrm{~mL}$ môi trường chứa vi tảo $H$. pluvialis từ bình chứa môi trường lỏng $\mathrm{BB}$ được sục khí ở các nghiệm thức khác nhau được dùng để thu sinh khối và xác định trọng lượng tươi và khô của vi tảo, sau đó thêm vào $12 \mathrm{~mL}$ chloroform và $24 \mathrm{~mL}$ methanol. Ly tâm 3.500 vòng/phút trong 15 phút. Thu dịch nổi, thêm $6,8 \mathrm{~mL}$ methanol, $1,2 \mathrm{~mL} \mathrm{NaOH} 0,1 \mathrm{~N}$ và $8 \mathrm{~mL}$ chloroform. Ü cách thủy ở $90^{\circ} \mathrm{C}$ trong 40 phút, để nguội. Thêm vào $4 \mathrm{~mL}$ nước cất để dung dịch phân thành ba lớp. Lớp dưới cùng là dầu sinh học (Bligh \& Dyer, 1959; Hossain et al., 2008, Wen \& Johnson, 
2009). Với phương pháp này, cả lipid tích lũy trong tế bào lẫn lipid thoát ra môi trường nuôi cấy đều được thu nhận bằng sự ester hóa các acid béo.

Tất cả các thi nghiệm được thực hiện với 3 lần lặp lại, mỗi lần với 3 bình 500mL chưa $250 \mathrm{~mL}$ môi truờng lỏng $B B$ được sục khi vào lúc 8 giờ sáng.

\section{Kết quả}

\section{(B) Ảnh hưởng của xử lý ánh sáng đèn LED trắng, đỏ và xanh}

(C) Xử lý ánh sáng trong 3 tuần: dưới đèn LED trắng: vi tảo vẫn còn màu xanh nhưng có sự phân hủy dần nội dung của tế bào, đèn LED đỏ làm cho phần lớn các tế bào vi tảo chuyển sang màu nâu sậm và nhiều tế bào bị phân hủy, trong khi đèn LED xanh làm cho tất cả các tế bào vi tảo bị phân hủy hoàn toàn (Hình 1.1).

Xử lý ánh sáng trong 24 giờ: dưới đèn LED trắng và đèn LED xanh: vi tảo có hình cầu và vẫn còn màu xanh với ánh sáng, nhưng mất dần nội dung với ánh sáng đèn LED đỏ (Hình 1.2).

(D) Xử lý ánh sáng gián đoạn đêm trong 30 phút: dưới đèn LED trắng: vi tảo có hình cầu hoặc hình elip và một số tế bào phóng thích nội dung, mất dần nội dung với ánh sáng đèn LED đỏ, một số tế bào chuyển sang màu đỏ với ánh sáng đèn LED xanh (Hình 1.3).

Trong các xử lý chiếu sáng bằng đèn LED xanh và đỏ liên tục trong 24 giờ hoặc gián đoạn đêm trong 30 phút vào lúc 0 giờ, chỉ có xử lý ánh sáng đèn LED đỏ trong 24 giờ làm tăng có ý nghĩa lượng dầu sinh học, nhưng làm giảm mạnh trọng lượng tươi và khô so với đối chứng (ánh sáng huỳnh quang) (Bảng 1).

\section{Bảng 1}

Ảnh hưởng của xử lý ánh sáng đèn LED trắng, đỏ và xanh lên sự tăng trưởng và tích lũy lipid của vi tảo trong bình chứa môi trường lỏng $\mathrm{BB}$ được sục khí

\begin{tabular}{|l|c|c|c|}
\hline \multicolumn{1}{|c|}{ Xử lý } & $\begin{array}{c}\text { Trọng lượng tươi } \\
(\mathbf{m g} / \mathbf{m L})\end{array}$ & $\begin{array}{c}\text { Trọng lượng khồ } \\
(\mathbf{m g} / \mathbf{m L})\end{array}$ & $\begin{array}{c}\text { Dầu sinh học } \\
(\mathbf{m g} / \mathbf{m L})\end{array}$ \\
\hline $\begin{array}{l}\text { Đối chứng } \\
\text { (đèn huỳnh quang) }\end{array}$ & $29,370^{\mathrm{a}}$ & $3,270^{\mathrm{a}}$ & $0,050^{\mathrm{b}}$ \\
\hline LED trắng, 24 giờ & $21,570^{\mathrm{b}}$ & $1,720^{\mathrm{c}}$ & $0,054^{\mathrm{ab}}$ \\
\hline LED đỏ, 24 giờ & $15,300^{\mathrm{c}}$ & $0,920^{\mathrm{d}}$ & $0,063^{\mathrm{a}}$ \\
\hline LED xanh, 24 giờ & $15,760^{\mathrm{c}}$ & $0,970^{\mathrm{d}}$ & $0,059^{\mathrm{ab}}$ \\
\hline LED trắng, 30 phút & $27,100^{\mathrm{a}}$ & $2,200^{\mathrm{b}}$ & $0,057^{\mathrm{ab}}$ \\
\hline LED đỏ, 30 phút & $26,870^{\mathrm{a}}$ & $2,180^{\mathrm{b}}$ & $0,058^{\mathrm{ab}}$ \\
\hline LED xanh, 30 phút & $27,000^{\mathrm{a}}$ & $2,280^{\mathrm{b}}$ & $0,055^{\mathrm{ab}}$ \\
\hline
\end{tabular}

Ghi chú: Các chữ cái theo sau số trung bình trong cùng một cột khác nhau biểu hiện sự khác biệt có ý nghĩa thống kê ở mức $\mathrm{P} \leq 0,05$

Nguồn: Kết quả phân tích dữ liệu của nhóm nghiên cứu 

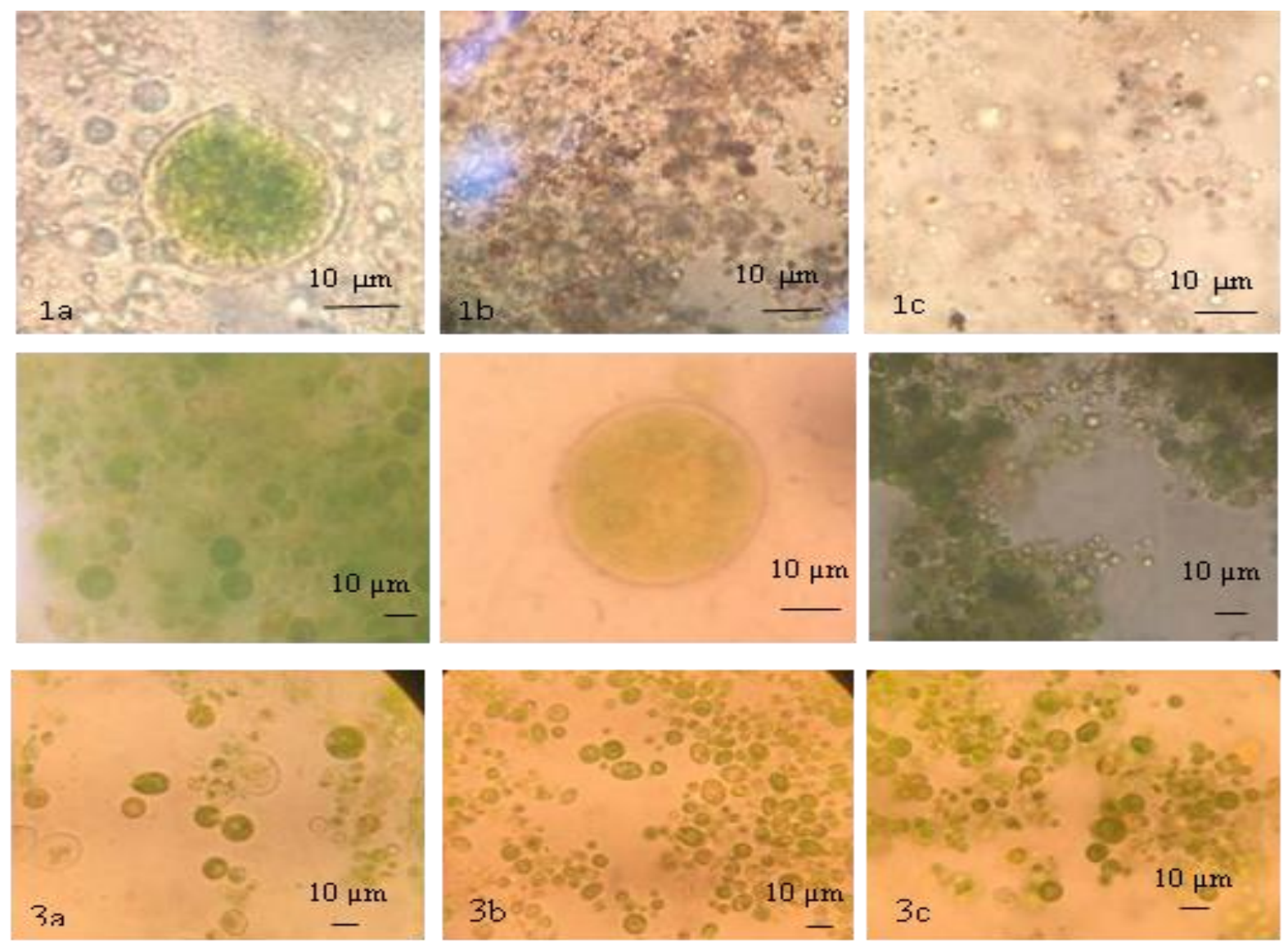

Hình 1. Vi tảo sau 7 tuần được nuôi cấy dưới ánh sáng đèn huỳnh quang trong bình chứa môi trường lỏng $\mathrm{BB}$ được sục khí và xử lý ánh sáng đèn LED

Ghi chú: Trong 3 tuần (1a) Trắng: màu lục, phân hủy nhiều (1b) Đỏ: màu nâu đỏ, phân hủy nhiều (1c) Xanh: phân hủy hoàn toàn

Trong 24 giờ (2a) Trắng: Vi tảo màu lục, phân hủy một phần (2b) Đỏ: Vi tảo màu đỏ, phân hủy nhiều (2c) Xanh: Vi tảo màu lục, phân hủy nhiều

Gián đoạn đêm 30 phút (3a) Trắng: Vi tảo màu lục, phân hủy một phần (3b) Đỏ: Một số vi tảo có màu đỏ, phân hủy một phần (3c) Xanh: Một vi số tảo có màu đỏ

\section{Ảnh hưởng của xử lý nhiệt độ}

Sau 7 tuần nuôi cấy vi tảo trong bình chứa môi trường lỏng $\mathrm{BB}$ được sục khí, trong số các xử lý nhiệt độ cao $\left(50^{\circ} \mathrm{C}\right)$ và thấp $\left(0 \pm 2^{\circ} \mathrm{C}\right)$ trong 1,5 hoặc 2 giờ, và xử lý nhiệt độ nhiệt độ $7 \pm 3^{\circ} \mathrm{C}$ trong $2,3,4$ hoặc 6 giờ, chỉ có xử lý $7 \pm 3^{\circ} \mathrm{C}$ trong 2 giờ làm tăng hàm lượng dầu sinh học và thay đổi không đáng kể trọng lượng tươi, nhưng giảm trọng lượng khô so với đối chứng (Bảng 2).

Cùng với sự thay đổi về hàm lượng dầu sinh học và trọng lượng tươi và khô, các xử lý nhiệt độ làm thay đổi hình thái của tế bào vi tảo. Sau 2 giờ xử lý ở $50^{\circ} \mathrm{C}$, vi tảo vẫn giữ hình cầu và có màu lục như đối chứng. Ở $0 \pm 2^{\circ} \mathrm{C}$, vi tảo có hình cầu và một số tế bào chuyển sang màu đỏ sau 1,5 giờ xử lý, nhưng phần lớn có màu đỏ và phóng thích nội dung ra ngoài môi trường sau 2 giờ xử lý (Hình 2). Ở $7 \pm 3^{\circ} \mathrm{C}$, các vi tảo chuyển dần sang màu đỏ sau 2 giờ xử lý, 
trong khi một số tế bào bị phân hủy và một số tế bào khác phân chia sau 3 giờ xử lý. Các tế bào có thể bị phân hủy, có màu đỏ hay vẫn giữ màu xanh sau 4 và 6 giờ xử lý (Hình 2).

\section{Bảng 2}

Ảnh hưởng của xử lý nhiệt độ lên sự tăng trưởng và tích lũy lipid của vi tảo trong bình chứa môi trường lỏng $\mathrm{BB}$ được sục khí

\begin{tabular}{|c|c|c|c|}
\hline Xử lý & $\begin{array}{c}\text { Trọng lượng tươi } \\
(\mathbf{m g} / \mathbf{m L})\end{array}$ & $\begin{array}{c}\text { Trọng lưọng khô } \\
(\mathbf{m g} / \mathbf{m L} \mathbf{L})\end{array}$ & $\begin{array}{c}\text { Dầu sinh học } \\
(\mathbf{m g} / \mathbf{m L} \mathbf{)}\end{array}$ \\
\hline Đối chứng $25 \pm 3^{\circ} \mathrm{C}$ & $29,370^{\mathrm{a}}$ & $3,800^{\mathrm{a}}$ & $0,052^{\mathrm{c}}$ \\
\hline $50^{\circ} \mathrm{C}, 2$ giờ & $29,000^{\mathrm{a}}$ & $2,470^{\mathrm{b}}$ & $0,053^{\mathrm{c}}$ \\
\hline $0 \pm 2^{\circ} \mathrm{C}, 1,5$ giờ & $24,170^{\mathrm{a}}$ & $2,400^{\mathrm{b}}$ & $0,061^{\mathrm{bc}}$ \\
\hline $0 \pm 2^{\circ} \mathrm{C}, 2$ giờ & $16,630^{\mathrm{ab}}$ & $1,600^{\mathrm{d}}$ & $0,061^{\mathrm{bc}}$ \\
\hline $7 \pm 3^{\circ} \mathrm{C}, 2$ giờ & $27,100^{\mathrm{ab}}$ & $2,200^{\mathrm{bc}}$ & $0,108^{\mathrm{a}}$ \\
\hline $7 \pm 3^{\circ} \mathrm{C}, 3$ giờ & $26,870^{\mathrm{ab}}$ & $2,180^{\mathrm{bcd}}$ & $0,069^{\mathrm{b}}$ \\
\hline $7 \pm 3^{\circ} \mathrm{C}, 4$ giờ & $27,000^{\mathrm{ab}}$ & $2,280^{\mathrm{bc}}$ & $0,060^{\mathrm{bc}}$ \\
\hline $7 \pm 3^{\circ} \mathrm{C}, 6$ giờ & $21,570^{\mathrm{b}}$ & $1,720^{\mathrm{cd}}$ & $0,060^{\mathrm{bc}}$ \\
\hline
\end{tabular}

Ghi chú: Các chữ cái theo sau số trung bình trong cùng một cột khác nhau biểu hiện sự khác biệt có ý nghĩa thống kê ở mức $\mathrm{P} \leq 0,05$

Nguồn: Kết quả phân tích dữ liệu của nhóm nghiên cứu

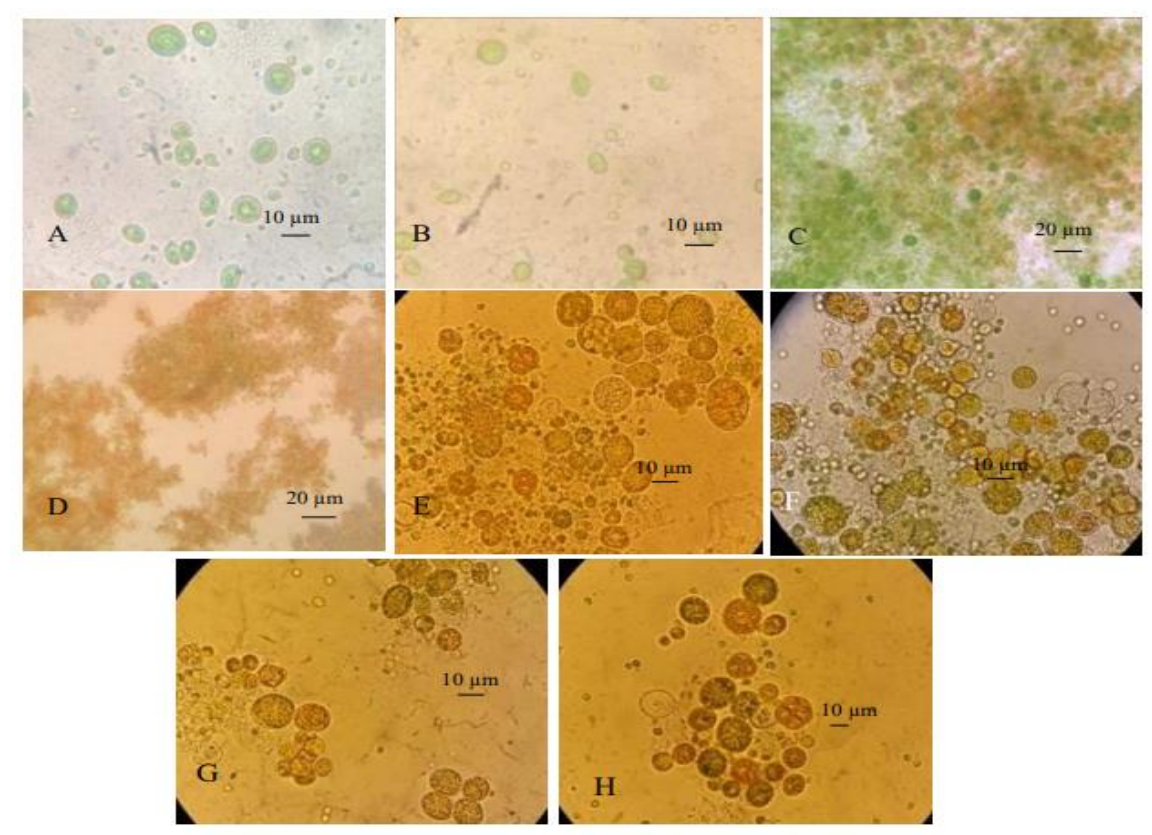

Hình 2. Vi tảo sau 7 tuần được nuôi cấy trong bình chứa môi trường lỏng BB được sục khí, xử lý nhiệt độ và quan sát ngay khi kết thúc thí nghiệm

Ghi chú: (A) Đối chứng: màu lục (B) $50^{\circ} \mathrm{C}, 2$ giờ: màu lục $(\mathrm{C}) 0 \pm 2{ }^{\circ} \mathrm{C} ; 1,5$ giờ: màu đỏ (D) $0 \pm 2{ }^{\circ} \mathrm{C} ; 2$ giờ: màu đỏ (E) $7 \pm 3{ }^{\circ} \mathrm{C}$; 2 giờ: màu đỏ $(\mathrm{F}) 7 \pm 3{ }^{\circ} \mathrm{C} ; 3$ giờ: màu đỏ hoặc lục, có sự phân hủy nội dung $(\mathrm{G}) 7 \pm 3{ }^{\circ} \mathrm{C} ; 4$ giờ: màu đỏ nhạt và phân hủy nội dung $(\mathrm{H}) 7 \pm 3{ }^{\circ} \mathrm{C} ; 6$ giờ: Một số tế bào vi tảo có màu đỏ hoặc lục, có sự phân hủy nội dung. 


\section{Ảnh hưởng của $\mathrm{Cu}^{2+}, \mathrm{Fe}^{2+}, \mathrm{Mg}^{2+}$ và $\mathrm{Zn}^{2+}$}

Sự bổ sung $\mathrm{CuSO}_{4}$ (2,355 hoặc 3,14mg/L), $\mathrm{FeSO}_{4}$ (7,47 hoặc 9,96mg/L), $\mathrm{MgSO}_{4}(112,5$ hoặc $150 \mathrm{mg} / \mathrm{L})$ và $\mathrm{ZnSO}_{4}(13,23$ hoặc $7,64 \mathrm{mg} / \mathrm{L})$ vào môi trường nuôi cấy ở tuần thứ 7 , trong 3 ngày, không làm thay đổi đáng kể hay làm giảm lượng dầu sinh học, dù các xử lý có thể gây thay đổi tăng trưởng, hình thái và màu sắc vi tảo: sự tăng nồng độ $\mathrm{FeSO}_{4}$ gấp 1,5 lần $(7,47 \mathrm{mg} / \mathrm{L})$ cảm ứng gia tăng mật độ tế bào, trong khi sự tăng nồng độ $\mathrm{CuSO}_{4}$ gấp 2 lần $(3,14 \mathrm{mg} / \mathrm{L})$ cảm ứng sự gia tăng trọng lượng tươi và cả trọng lượng khô của vi tảo (Bảng 3, Hình 3).

\section{Bảng 3}

Ảnh hưởng của kim loại nặng sau 3 ngày xử lý lên sự tăng trưởng của vi tảo sau 7 tuần nuôi cấy

\begin{tabular}{|c|c|c|c|c|c|}
\hline \multicolumn{2}{|c|}{ Xử lý } & $\begin{array}{l}\text { Mật độ tế bào } \\
\left(\mathbf{x} 10^{3} \text { tb/ mL) }\right.\end{array}$ & $\begin{array}{l}\text { Trọng lượng } \\
\text { tươi (mg/mL) }\end{array}$ & $\begin{array}{l}\text { Trọng lượng } \\
\text { khồ (mg/mL) }\end{array}$ & $\begin{array}{c}\text { Dầu sinh học } \\
(\mathrm{mg} / \mathrm{mL})\end{array}$ \\
\hline \multicolumn{2}{|c|}{ Đối chứng } & $100,670^{\mathrm{b}}$ & $79,330^{\mathrm{bc}}$ & $2,330^{\mathrm{b}}$ & $0,049^{\mathrm{a}}$ \\
\hline \multirow{2}{*}{$\begin{array}{l}\mathrm{CuSO}_{4} \\
(\mathrm{mg} / \mathrm{L})\end{array}$} & 2,355 & $52,670^{c}$ & $137,330^{\mathrm{bc}}$ & $4,000^{\mathrm{b}}$ & 0,000 \\
\hline & 3,14 & $130,700^{\mathrm{b}}$ & $427,000^{\mathrm{a}}$ & $23,330^{\mathrm{a}}$ & $0,080^{\mathrm{a}}$ \\
\hline \multirow{2}{*}{$\begin{array}{l}\mathrm{FeSO}_{4} \\
(\mathrm{mg} / \mathrm{L})\end{array}$} & 7,47 & $184,000^{\mathrm{a}}$ & $131,000^{\mathrm{bc}}$ & $5,000^{\mathrm{b}}$ & $0,080^{\mathrm{a}}$ \\
\hline & 9,96 & $41,670^{c}$ & $77,000^{c}$ & $2,000^{\mathrm{b}}$ & $0,083^{\mathrm{a}}$ \\
\hline \multirow{2}{*}{$\begin{array}{c}\mathrm{MgSO}_{4} \\
(\mathrm{mg} / \mathrm{L})\end{array}$} & 112,5 & $50,330^{c}$ & $159,670^{\mathrm{bc}}$ & $5,330^{\mathrm{b}}$ & 0,000 \\
\hline & 150 & $46,000^{c}$ & $237,670^{b}$ & $10,000^{\mathrm{b}}$ & 0,000 \\
\hline \multirow{2}{*}{$\begin{array}{l}\mathrm{ZnSO}_{4} \\
(\mathrm{mg} / \mathrm{L})\end{array}$} & 13,23 & $43,670^{c}$ & $143,670^{\mathrm{bc}}$ & $4,330^{\mathrm{b}}$ & 0,000 \\
\hline & 7,64 & $13,670^{c}$ & $103,670^{\mathrm{bc}}$ & $2,000^{\mathrm{b}}$ & 0,000 \\
\hline
\end{tabular}

Ghi chú: Các chữ cái theo sau số trung bình trong cùng một cột khác nhau biểu hiện sự khác biệt có ý nghĩa thống kê ở mức $\mathrm{P} \leq 0,05$.

Nguồn: Kết quả phân tích dữ liệu của nhóm nghiên cứu 

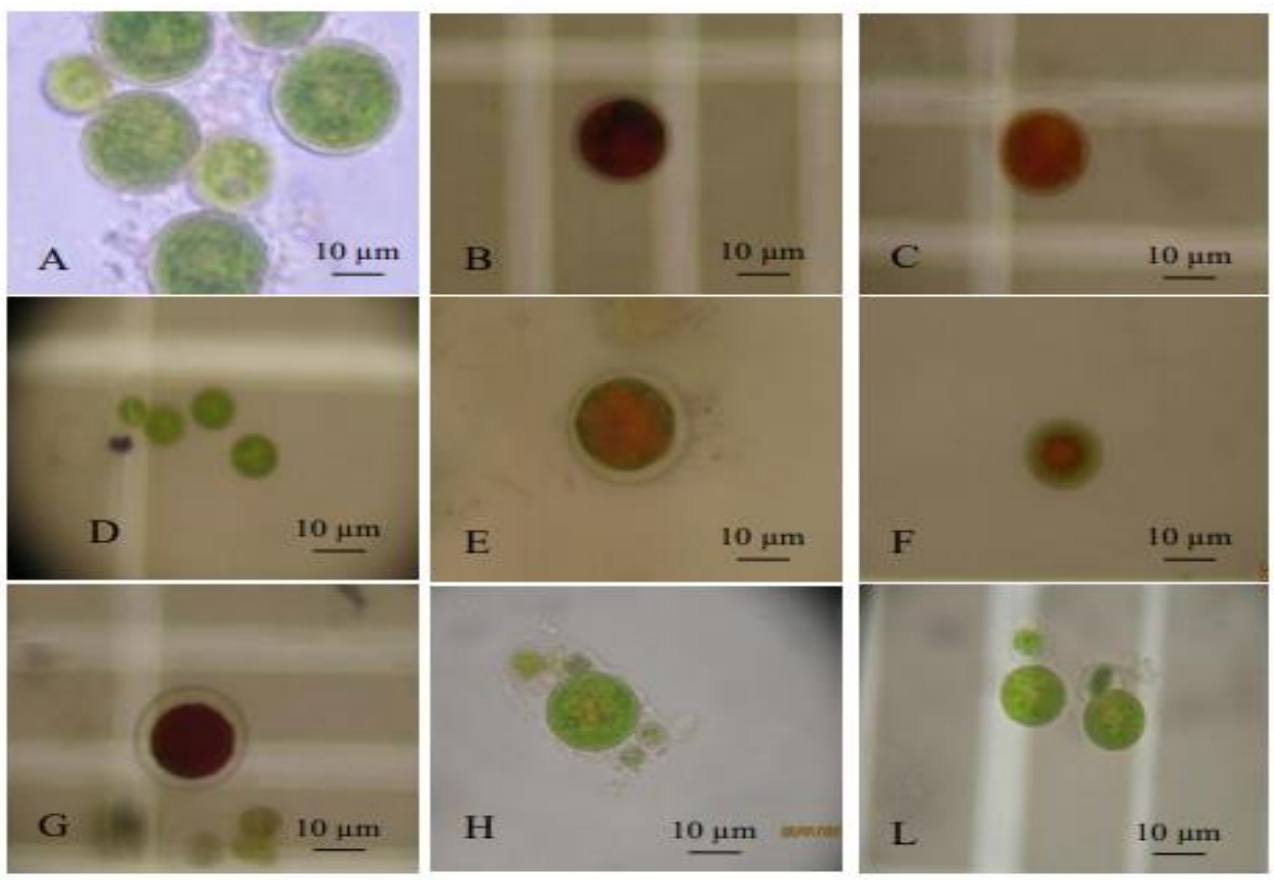

Hình 3. Vi tảo sau 3 tuần được nuôi cấy trong bình chứa môi trường lỏng $B B$ được sục khí và xử lý kim loại trong 3 ngày

Ghi chú: (A) Đối chứng: màu lục, vách mỏng; (B) $\mathrm{MgSO}_{4}$ 112,5mg/L: màu cam, vách dày; (C) $\mathrm{MgSO}_{4} 150 \mathrm{mg} / \mathrm{L}$ : màu cam, vách dày; (D) $\mathrm{FeSO}_{4} 7,98 \mathrm{mg} / \mathrm{L}$ : màu lục, vách mỏng; (E) $\mathrm{FeSO}_{4} 9,96 \mathrm{mg} / \mathrm{L}$ : màu cam, vách dày; (F) $\mathrm{CuSO}_{4}$ 2,355mg/L: màu cam, vách mỏng; $(\mathrm{G}) \mathrm{CuSO}_{4} 3,14 \mathrm{mg} / \mathrm{L}$ : màu đỏ, vách rất dày; $(\mathrm{H}) \mathrm{ZnSO}_{4} 13,23 \mathrm{mg} / \mathrm{L}$ : màu lục; (I) $\mathrm{ZnSO}_{4} 26,46 \mathrm{mg} / \mathrm{L}$ : màu lục với một số tế bào bị phân hủy

\section{Ảnh hưởng của $\mathrm{NaCl}$}

$\mathrm{NaCl} 0,5 \%$, làm tăng lượng dầu sinh học trích được so với đối chứng, nhưng làm giảm trọng lượng tươi và khô (Bảng 4 ). Trong môi trường với $\mathrm{NaCl}$ ở nồng độ từ $0,9 \%$ đến $3 \%$, tế bào vi tảo có màu đỏ, vách rất dày. Nồng độ muối càng cao, vách tế bào càng dày và rất nhiều tế bào bị phân hủy trong môi trường (Hình 4).

\section{Bảng 4}

Ảnh hưởng của $\mathrm{NaCl}$ ở các nồng độ khác nhau lên sự tăng trưởng của vi tảo trong bình chứa môi trường lỏng $\mathrm{BB}$ được sục khí sau 3 tuần xử lý

\begin{tabular}{|c|c|c|c|}
\hline $\begin{array}{c}\text { NaCl } \\
(\mathbf{\%})\end{array}$ & $\begin{array}{c}\text { Trọng lượng tươi } \\
(\mathbf{m g} / \mathbf{m L})\end{array}$ & $\begin{array}{c}\text { Trọng lượng khô } \\
(\mathbf{m g} / \mathbf{m L})\end{array}$ & $\begin{array}{c}\text { Dầu sinh học } \\
(\mathbf{m g} / \mathbf{m L})\end{array}$ \\
\hline 0,0025 (Đối chứng) & $12,000^{\mathrm{a}}$ & $3,070^{\mathrm{a}}$ & $0,050^{\mathrm{b}}$ \\
\hline 0,5 & $6,870^{\mathrm{b}}$ & $1,040^{\mathrm{b}}$ & $0,640^{\mathrm{a}}$ \\
\hline 0,9 & $2,500^{\mathrm{b}}$ & $1,630^{\mathrm{ab}}$ & $0,110^{\mathrm{b}}$ \\
\hline 1,5 & $3,330^{\mathrm{b}}$ & $2,040^{\mathrm{ab}}$ & $0,090^{\mathrm{b}}$ \\
\hline 3,0 & $1,400^{\mathrm{b}}$ & $2,380^{\mathrm{ab}}$ & $0,060^{\mathrm{b}}$ \\
\hline
\end{tabular}

Ghi chú: Các chữ cái theo sau số trung bình trong cùng một cột khác nhau biểu hiện sự khác biệt có ý nghĩa thống kê ở mức $\mathrm{P} \leq 0,05$

Nguồn: Kết quả phân tích dữ liệu của nhóm nghiên cứu 

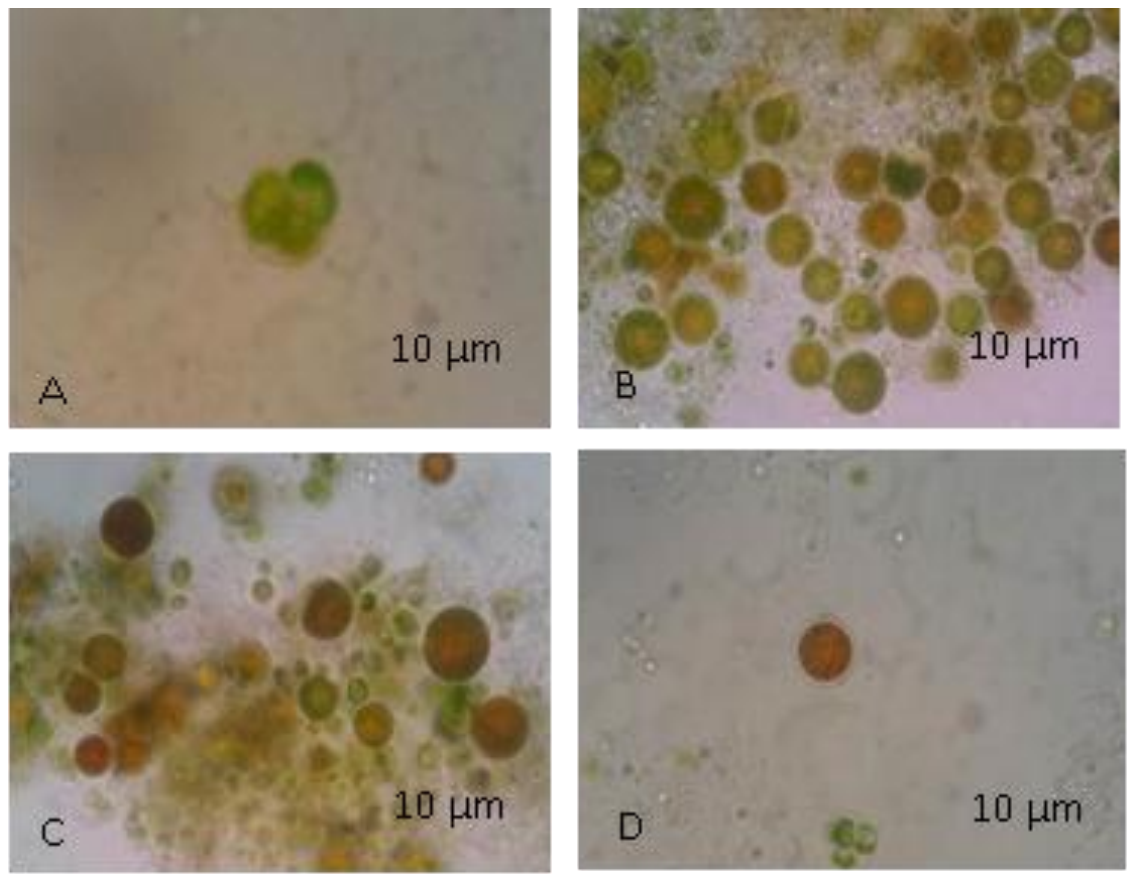

Hình 4. Vi tảo sau 7 tuần nuôi cấy trong bình chứa môi trường lỏng $\mathrm{BB}$ được sục khí và xử lý với các nồng độ $\mathrm{NaCl}$ trong 3 tuần

Ghi chú: (A) 0,5\%: màu lục; (B) 0,9\%: màu đỏ; (C) 1,5\%: màu đỏ; (D) 3,0\%: màu đỏ, vách dày, tế bào phân hủy nhiều

\section{Thảo luận}

Các loại ánh sáng LED trắng, LED đỏ và LED xanh ở các thời gian xử lý khác nhau trong nghiên cứu này làm giảm sự tăng trưởng và không kích thích sự tích lũy lipid ở vi tảo. Điều này có lẽ do cường độ ánh sáng chưa thích hợp. Quá trình thích nghi/đáp ứng với ánh sáng phụ thuộc vào quá trình quang hợp, thông qua nhiều biến đổi liên quan tới kiểu và số lượng các sắc tố, tăng trưởng vi tảo, hô hấp tối và các acid béo cơ bản (Dubinsky, Matsukawa, \& Karube, 1995). Bên cạnh cường độ, chu kỳ và phổ ánh sáng cũng có ảnh hưởng trên tảo. Phổ ánh sáng 300 - 400nm (gần tia UV) hoặc 400 - 480nm (ánh sáng xanh lơ) tốt hơn 620 - 750nm (ánh sáng đỏ). Khi dùng ánh sáng đỏ cần bổ sung một ít photon của ánh sáng xanh lơ. Ngoài năng lượng, các thành phần đặc biệt của ánh sáng có tác động trong các quá trình điều hòa nội bào gồm: tổng hợp chlorophyll, sửa chữa hư hỏng do ánh sáng và phân chia tế bào.

Nhiệt độ cao $50^{\circ} \mathrm{C}$ trong 2 giờ, không làm tế bào vi tảo chuyển đổi trạng thái và tăng tổng hợp lipid. Điều này chưa phù hợp với nghiên cứu của Lei và cộng sự (2012), nhiệt độ $42^{\circ} \mathrm{C}$ trong bốn ngày kích thích vi tảo tổng hợp acid béo. Có lẽ, trong nghiên cứu này, thời gian xử lý chưa đủ và vi tảo này được phân lập ở Việt Nam nên thích nghi với nhiệt độ cao. Nhiệt độ thấp $7 \pm 3^{\circ} \mathrm{C}$ làm giảm sự tăng trưởng nhưng kích thích sự tích lũy lipid ở vi tảo. Lúc này, các tế bào vi tảo chuyển sang màu đỏ, vách tương đối dày. Sự tổng hợp astaxanthin vào lúc này có lẽ giúp vi tảo chống chịu với stress nhiệt độ (Bảng 2, Hình 2). Nhiệt độ quá cao hay quá thấp ảnh hưởng đến sự tăng trưởng của vi tảo giống như ở thực vật. Nhiệt độ cao gây mất cân bằng giữa hô hấp và quang hợp. Quang hợp và hô hấp đều giảm nhưng quang hợp giảm nhanh hơn hô hấp. Nhiệt độ cao làm xáo trộn màng thylakoid trước khi giảm hoạt tính enzyme quang hợp. 
Nhiệt độ cao còn làm giảm tính bền của các màng tế bào. Tuy nhiên, một số sinh vật đơn bào có thể hoàn tất chu trình sống ở $50^{\circ} \mathrm{C}$. Nhiệt độ thấp làm sự tăng trưởng bị chậm lại, thoát các chất hòa tan do làm giảm tính lỏng của màng plasma (Bui, 2016).

$\mathrm{FeSO}_{4}$ gấp 1,5 lần kích thích sự gia tăng mật độ tế bào và tích lũy lipid ở vi tảo. Tuy nhiên, sự gia tăng mật độ tế bào $\left(184 \times 10^{3}\right.$ tế bào/mL) không đi kèm với sự tích lũy chất khô $(5,00 \mathrm{mg} / \mathrm{mL})$ (Bảng 3). $\mathrm{FeSO}_{4}$ gấp 2 lần không kích thích sự gia tăng mật độ tế bào nhưng kích thích sự tích lũy lipid. Harker, Tsavalos, và Young (1996), nghiên cứu ảnh hưởng của Fe ở nồng độ $36,0 \mu \mathrm{M}$ (gấp 2 lần) và $72,0 \mu \mathrm{M}$ (gấp 4 lần so với đối chứng là $18 \mu \mathrm{M}$ trong môi trường $\mathrm{BB}$ ) trong 7 ngày cho thấy $\mathrm{Fe} 36 \mu \mathrm{M}$ làm giảm nhẹ mật độ tế bào và tăng nhẹ tích lũy astaxanthin. Ngược lại, $\mathrm{Fe} 7,2 \mu \mathrm{M}$ làm giảm mật độ tế bào nhưng kích thích tích lũy astaxanthin ở vi tảo $H$. pluvialis. Như vậy, sắt có thể kích thích sự tăng trưởng hoặc sự tích lũy lipid và astaxanthin tùy theo nồng độ. Fe là thành phần của nhiều enzyme (hiện diện trong vòng porphyrin của cytochrome, catalase và peroxidase), và có vai trò quan trọng trong sinh tổng hợp chlorophyll (Bui, 2016). Fe là khoáng vi lượng quan trọng cho sự tăng trưởng bình thường, chức năng quang hợp và hô hấp, hoạt động như chất xúc tác trong quang hợp, đồng hóa nitrogen (nitrogen assimilation) và các phản ứng chuyển electron ở sinh vật quang hợp (Terry \& Abadía, 1986). Thiếu hụt $\mathrm{Fe}$ làm giảm chuyển electron trong quang hợp dẫn tới sự hình thành NADPH. Tăng nồng độ Fe kích thích sự gia tăng lipid (Liu, Wang, \& Zhou, 2008). $\mathrm{CuSO}_{4}$ gấp 2 lần giúp tế bào vi tảo tích lũy các chất khô, nhưng lượng dầu sinh học gia tăng nhưng không có ý nghĩa so với đối chứng (Bảng 3). Cu liên kết với plastocyanin, enzyme chuyển electron trong quang hợp (Bui, 2016). $\mathrm{Cu}$ là một trong các kim loại gây độc $(\mathrm{Cu}, \mathrm{Ni}, \mathrm{Fe}, \mathrm{Zn})$ cho tế bào tảo ở nồng độ cao. Các kim loại này có thể ức chế cố định carbon và làm chậm hấp thu các chất dinh dưỡng (Rai \& Mallick, 1993).

$\mathrm{NaCl} 0,5 \%$ kích thích tế bào vi tảo tạo lipid. Khi nồng độ $\mathrm{NaCl}$ cao hơn $0,9 \%$, tế bào vi tảo chuyển sang trạng thái stress tạo nang, nội dung tế bào màu đỏ và vách tế bào rất dày (Bảng 4, Hình 4). Các kết quả nghiên cứu này phù hợp với nghiên cứu của Sarada, Tripathi, và Ravishankar (2002). Nồng độ $\mathrm{NaCl}$ cao gây cản tăng trưởng, xáo trộn cân bằng nước, và gia tăng áp suất thẩm thấu. Nhiễm muối (salinity) hay stress nồng độ muối cao (salinity stress), hiễm sodium (sodicity) và stress nước (water stress) có liên quan chặt chẽ với nhau. Ở thực vật, nhiễm muối hay nhiễm sodium $\left(\mathrm{Na}^{+}\right)$cản tăng trưởng và quang hợp và gây xáo trộn cân bằng nước vì thế nước bên ngoài hệ thống thực vật bị hạ thấp (Bui, 2016). Sự thay đổi nồng độ muối cao hơn hoặc thấp hơn điều kiện sống tự nhiên của tảo đều ảnh hưởng đến tăng trưởng và thay đổi thành phần, và nồng độ muối cao làm gia tăng thành phần lipid trong tảo (Zhila, Kalacheva, \& Volova, 2011).

\section{Kết luận}

Ánh sáng đèn LED (liên tục hoặc gián đoạn) chưa kích thích sự tăng trưởng và tích lũy lipid ở vi tảo. Xử lý nhiệt độ $7 \pm 3^{\circ} \mathrm{C}$ trong 2 giờ, $\mathrm{CuSO}_{4}$ gấp 2 lần, $\mathrm{FeSO}_{4}$ gấp 1,5 hoặc 2 lần hoặc xử lý $\mathrm{NaCl}$ 0,5\% kích thích sự tích lũy lipid ở vi tảo. 


\section{LỜI CẢM ƠN:}

Các tác giả xin chân thành cảm ơn phòng Công nghệ Tảo, Viện Công nghệ Sinh học thuộc Viện Hàn lâm Khoa học và Công nghệ Việt Nam, Hà Nội đã cho phép sử dụng nguồn vật liệu này.

\section{Tài liệu tham khảo}

Bligh, E. G., \& Dyer, W. J. (1959). A rapid method of total lipid extraction and purification. Canadian Journal of Biochemistry and Physiology, 37(8), 911-917. doi:10.1139/o59-099

Bui, V. T. (2016). Sinh lý thực vật đại cuoong [General plant physiology]. Ho Chi Minh, Vietnam: Trường Đại học Khoa học Tự nhiên, đại học Quốc Gia Thành phố Hồ Chí Minh.

Dubinsky, Z., Matsukawa, R., \& Karube, I. (1995). Photobiological aspects of algal mass culture. Journal of Marine Biotechnology, 2, 61-65.

Harker, M., Tsavalos, A. J., \& Young, A. J. (1996). Factors responsible for astaxanthin formation in the chlorophyte Haematococcus pluvialis. Bioresource Technology, 55(33), 207-214.

Hossain, M. I., Iwasaki, H., Okochi, Y., Chahine, M., Higashijima, S., Nagayama, K., \& Okamura, Y. (2008). Enzyme domain affects the movement of the voltage sensor in ascidian and zebrafish VSPs. The Journal of biological chemistry, 283(26), 18248-18259.

Lei, A., Chen, H., Shen, G., Hu, Z., Chen, L., \& Wang, J. (2012). Expression of fatty acid synthesis genes and fatty acid accumulation in Haematococcus pluvialis under different stressors. Biotechnology for Biofuels, 5(18), 2-11.

Liu, Z. Y., Wang, G. C., \& Zhou, B. C. (2008). Effect of iron on growth and lipid accumulation in Chlorella vulgaris. Bioresource Technology, 99, 4717-4722.

Nguyen, P. T. D., Lao, T. D., Le, T. H. A., \& Bui, V. T. (2016). Initial studies on Biotin carboxylase (BC) and acyl-acyl carrier protein thioesterase (FATA) genes in Haematococcus pluvialis Flotow. Journal of Biotechnology, 14(1A), 531-538.

Nguyen, P. T. D., Le, T. H. A., \& Bui, V. T. (2015). Ảnh hưởng cùa các chất điều hòa sinh trưởng thực vật lên sự sinh trưởng của vi tảo Haematococcus pluvialis Flotow [Effect of plant growth regulators on the growth of microalgae Haematococcus pluvialis Flotow]. Tạp chi Công nghệ Sinh học, 13(2), 269-247.

Rai, L., \& Mallick, N. (1993). Heavy metal toxicity to algae under synthetic microcosm. Ecotoxicology, 2, 231-242.

Sarada, R., Tripathi, U., \& Ravishankar, G. A. (2002). Influence of stress on astaxanthin production in Haematococcus pluvialis grown under different culture conditions. Process Biochemitry, 37(6), 623-627.

Terry, N., \& Abadía, J. (1986). Function of iron in chloroplasts. Journal of Plant Nutrition, 9(3/7), 609-646. 
Wen, Z., \& Johnson, M. B. (2009). Microalgae as a feedstock for biofuel production. Retrieved May 15, 2017, from https://www.pubs.ext.vt.edu/content/dam/pubs_ext_vt_edu/422/442-886/442886_pdf.pdf

Zhila, N. O., Kalacheva, G. S., \& Volova, T. G. (2011). Effect of salinity on biochemical composition of the alga Botryococcus braunii Kutz IPPAS H-252. Journal of Applied Phycology, 23(1), 47-52. 